\title{
A Report of 13 Cases of Merkel Cell Carcinoma: Single-Center Experience and Review of the Literature
}

\author{
Serkan Yazici, Elif Irmak Yazici, Saduman Balaban Adim, Emel Bulbul Baskan, Kenan Aydoğan, \\ Hayriye Saricaoğlu
}

Departments of Dermatology and Venereology and ${ }^{1}$ Pathology, Uludag University School of Medicine, Bursa, Turkey

Background: There is limited data knowledge of Merkel cell carcinoma (MCC) in Turkey aside from a few case reports. Objective: The aim of this study was to describe the clinical characteristics, demographic features, therapeutic parameters, and outcome of primary cutaneous MCC cases from Turkey. Methods: Digital medical records of the 13 MCC patients who were followed-up at a tertiary referral center were retrospectively analyzed. Clinic, demographic, tumor characteristics, and survival of the patients were retrieved. Results: Most of our patients were elderly. Female predominance was noticed. The most common primary site of the tumors was the lower extremities. The overall survival was 42 months, $68 \%$ at first year, $68 \%$ at third years, and $29 \%$ at fifth years. Conclusion: This is the first largest report from Turkish population with female predominance, and lower extremity tendency. (Ann Dermatol 31(3) $272 \sim 278,2019$ )

\section{-Keywords-}

Mechanoreceptor, Merkel cell, Merkel cell carcinoma, Neuroendocrine carcinoma, Pathogenesis, Prognosis, Trabecular carcinoma

Received May 29, 2018, Revised October 31, 2018, Accepted for publication November 14, 2018

Corresponding author: Serkan Yazici, Department of Dermatology and Venereology, Uludag University School of Medicine, 16059, GörükleNilüfer Bursa, Turkey. Tel: 90-224-42950721, Fax: 90-224-4429229, E-mail: serkanyazici@uludag.edu.tr ORCID: https://orcid.org/0000-0001-6407-0962

This is an Open Access article distributed under the terms of the Creative Commons Attribution Non-Commercial License (http://creativecommons. org/licenses/by-nc/4.0) which permits unrestricted non-commercial use, distribution, and reproduction in any medium, provided the original work is properly cited.

Copyright (c) The Korean Dermatological Association and The Korean Society for Investigative Dermatology

\section{INTRODUCTION}

Merkel cell carcinoma (MCC) is a rare cutaneous malignancy with a poor prognosis ${ }^{1}$. It was first described in 1972 as an indolent disease ${ }^{2}$. The current literature indicates that the disease has an aggressive course, and higher mortality rates than melanoma (approximately $46 \%$ vs. $12 \%$ ) with increasing incidence ${ }^{3,4}$. Previous morphological studies reported that MCC originated from Merkel cells (MCs) in the basal layer of the epidermis. It has been demonstrated that these tumors originate from totipotential stem cells that exhibit epithelial and neuroendocrine properties during malignant transformation ${ }^{5,6}$. The annual incidence is variable and ranges between 0.11 to 1.6 cases per 100,000, and higher incidence rates were reported in Australia and New Zealand. MCC is typically seen in older individuals, with a mean age at diagnosis of 76 years for females and 74 years for males. Incidence rates were higher in males than females ${ }^{7-9}$.

Although the pathogenesis of MCC is not completely known, multiple factors contribute to the etiopathogenesis of MCC including older age, increased aggregate ultraviolet (UV) exposure, immunosuppression, and Merkel Cell Polyomavirus (MCPyV) infection ${ }^{1}$. MCC typically presents as a rapidly growing, painless, firm, non-tender, shiny, flesh-colored or bluish-red, intra cutaneous nodule. Early tumors are usually misdiagnosed as benign lesions (e.g., cyst, lipoma, pyogenic granuloma). Early recognition of MCC is important since the expected 5 years survival is $79 \%$ in the early stage (IA), unfortunately only $18 \%$ by the time of metastasis (stage IV). High clinical suspicion and early diagnosis may improve survival rates ${ }^{10}$. Due to its rarity epidemiological data are scarce, and have not been previously analyzed in Turkey to identify the main epidemiological trends. The aim of this study was to describe 
the clinical characteristics, demographic features, therapeutic parameters, and outcome of MCC cases from Turkey.

\section{MATERIALS AND METHODS}

\section{Patients}

We retrospectively analyzed the digital medical records of the 13 patients who were followed-up between January 2008 and January 2018 with the diagnosis of primary cutaneous MCC. Our tertiary referral center is located in the south east Marmara region of Turkey about 5 million population. Basic patient demographics (age of onset, gender), past medical history (diabetes mellitus, hypertension, coronary artery disease and malignancy), tumor characteristics (duration of the lesion, localization, maximum tumor size), treatment parameters including surgical margin, tumor, node, metastasis (TNM) stage, treatment modalities, follow-up period, recurrence, and survival status were retrieved from computerized medical records. Immunosuppression status was considered positive if the patients had any history of solid organ transplantation, were taking chronic immunosuppressive or chemotherapeutic drugs, or had a prior or current diagnosis of chronic leukemia or lymphoma $^{11}$. Ethical approval was obtained from the ethics committee of the Uludag University (approval number: 2017-14/39). Written informed consent was obtained from the patient or legal guardian to report and publish the identifiable patient images.

\section{Diagnosis and management}

Histopathological diagnosis required that the tumor morphology was consistent with MCC on hematoxylin-eosinstained tissue sections and that the specimens were immunohistochemically positive for cytokeratin 20 (CK20). If CK20 was negative, but morphology consistent with MCC, the diagnosis was confirmed by immunostaining for Synaptophysin and Chromogranin A. Negative immunostaining for thyroid transcriptase factor 1 was required to rule out metastatic small cell lung carcinoma ${ }^{12}$.

Clinical or radiological evidence of lymph node involvement or distant metastasis were evaluated for all patients with a biopsy-confirmed cutaneous MCC. Management of the primary lesion included wide local excision (WLE) with margins of at least $2 \mathrm{~cm}$ of normal appearing skin wherever possible, adjuvant radiotherapy (RT), chemotherapy (CT) or a combination of these modalities were recommended as individual basis. The tumors were staged according to the American Joint Committee on Cancer (AJCC) staging recommendations. Overall survival (OS) was measured from the date of presentation to the date of death from any cause ${ }^{13}$.

\section{Statistical analysis}

Statistical analyses were performed by IBM SPSS Statistics for Windows ver. 20.0 (IBM Co., Armonk, NY, USA). Mean \pm standard deviation were calculated for continuous variables, while percentiles and frequencies were reported for categorical variables. The Kaplan-Meier method was used for survival estimations and the log-rank test was used for survival curve comparisons. All comparisons were two-tailed, with a p-value of 0.05 or less considered to statistical significance.

\section{RESULTS}

Total of 13 patients were followed-up during 10 years period. Mean age at the onset of the lesions was $71.23 \pm 10.83$ with median was 69 years. Female predominance $(61.5 \%)$ was noticed. None of the preliminary clinical diagnosis was MCC before the histological examination. All diagnoses were confirmed by immunostaining (Table 1). The duration of the lesions was $\leq 3$ months in nine $(69.2 \%)$ patients. The most common primary site of the tumors was the lower extremities (Fig. 1) followed by head and neck (Fig. 2), and $77 \%$ of lesions were located on the extremities. One $(7.7 \%)$ of patients had a tumor at a highly sun-protected site (buttock), and one patient (7.7\%) had tumor arise on partially protected sites (thighs) (Fig. 3). One male patient had bilateral lesions. While more than $90 \%$ of the lesions were asymptomatic, pain was noticed with a $10 \mathrm{~cm}$ tumor with 12 months' duration. Concom-

Table 1. Immunocytochemical profile of the patients

\begin{tabular}{ccccccc}
\hline $\begin{array}{c}\text { Patient } \\
\text { number }\end{array}$ & $\begin{array}{c}\text { Synapto- } \\
\text { physin }\end{array}$ & $\begin{array}{c}\text { Chromo- } \\
\text { granine A }\end{array}$ & CK20 & CK7 & NSE & TTF1 \\
\hline 1 & + & + & + & - & + & - \\
2 & + & + & + & - & + & - \\
3 & + & + & - & - & + & - \\
4 & + & - & - & - & + & - \\
5 & + & + & + & - & + & - \\
6 & + & - & + & - & + & - \\
7 & + & + & + & - & + & - \\
8 & NA & NA & + & - & + & - \\
9 & + & + & + & - & NA & - \\
10 & + & + & + & - & + & - \\
11 & + & + & + & - & NA & - \\
12 & + & + & + & - & + & - \\
13 & + & - & + & - & + & - \\
\hline
\end{tabular}

CK: cytokeratin, NSE: neuron-specific enolase, TTF1: thyroid transcription factor 1, NA: not assessed, +: positive stain, - : negative stain. 


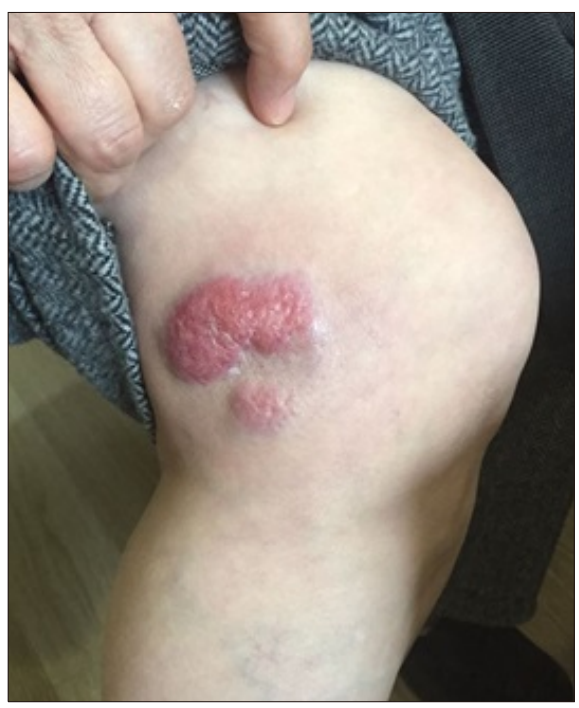

Fig. 1. A representative case of Merkel cell carcinoma with a $5 \times 3.5 \times 3 \mathrm{~cm}$ nodule for the last three months on the right knee (patient no. 3).

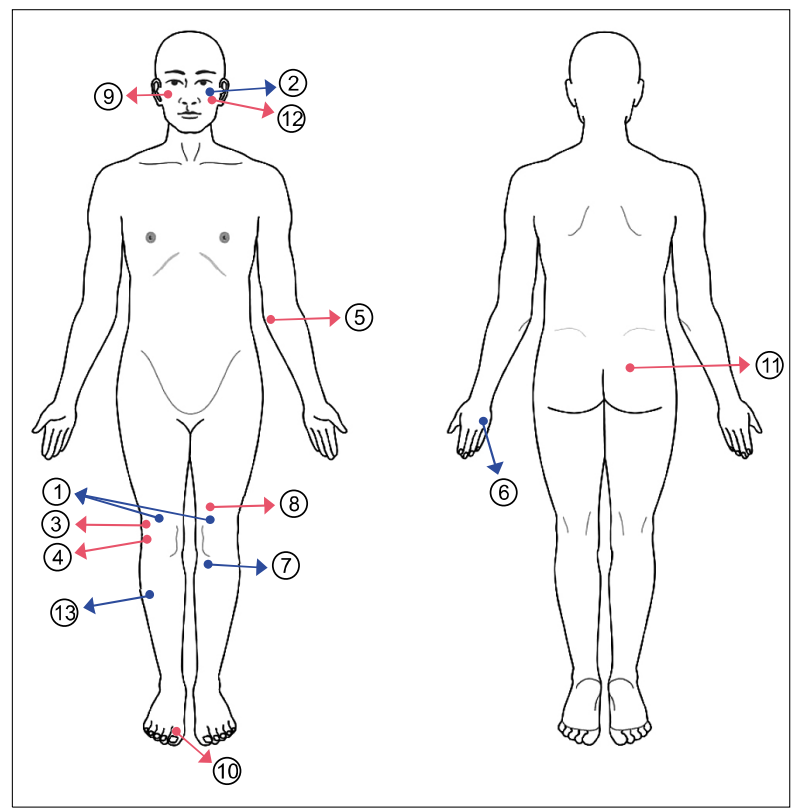

Fig. 3. Diagram of the primary tumor distribution at presentation in 13 patients. Blue color indicates male and pink color indicates female patients, and numbers is the sequence number as in Table 3. Accumulation of primary tumors around the high pressure joint like knee took our attention.

itant malignancy (diagnosed prior, after or during the initial evaluation of the MCC diagnosis) was detected in four cases including; papillary thyroid carcinoma in one patient diagnosed six months after the diagnosis of MCC and breast carcinoma $\left(\mathrm{T}_{1} \mathrm{~N}_{0} \mathrm{M}_{0}\right)$ in another patient diagnosed two years before the diagnosis of MCC. One patient had a

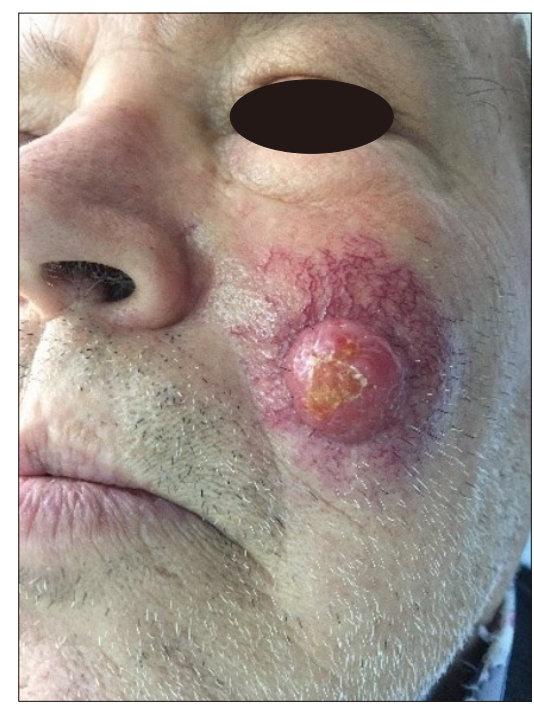

Fig. 2. A representative case of Merkel cell carcinoma with a $2.5 \times 2 \times 3.1 \mathrm{~cm}$ fast-growing telangiectasic nodule for the last three months on the left malar area (patient no. 2).

15 years history of stage III chronic lymphocytic leukemia (CLL) without any medication and simultaneous basosquamous cancer. One patient had simultaneous breast carcinoma (patient numbers 2, 8, 9, and 11 respectively). Two of the patients had a history of immunosuppression due to CT for CLL and breast carcinoma. Seven patients had long-term comorbidities including diabetes mellitus, hypertension, and coronary artery disease, which some authors described as immunocompromised patients ${ }^{14}$.

At presentation, 39\% of the lesions were confined to the skin (AJCC stage 1 2). Within a median 15 months follow-up only one patient developed metastasis on the regional nodes after 12 months who had a $1 \times 1 \mathrm{~cm}$ primary tumor on the hand, and treated with only WLE without RT (patient number 6). During the follow-up period six (46.2\%) patients were died; seventh patient was dead due to cardiovascular arrest at third years of follow-up unrelated with treatment, ninth patient was dead within three months after MCC diagnosis, during initial evaluation who had history of stage III CLL for 15 years without any treatment, tenth patient was dead at first year of follow-up unrelated with treatment, eleventh patient was dead at first year of the follow-up due to febrile neutropenia after $\mathrm{CT}$, twelfth patient was dead at fifth years of follow-up unrelated to treatment, and thirteen patient was dead within first year due to febrile neutropenia after CT. Epidemiological, clinical, and demographical characteristics of the patients were presented in Table 2, 3. OS was 42 months (Fig. 4), and $68 \%$ at first year, $68 \%$ at third years, and $29 \%$ at fifth years. The effect of factors on survival could not be eval- 
Table 2. Characteristics of the patients

\begin{tabular}{|c|c|}
\hline Characteristic & Value \\
\hline Total number & 13 \\
\hline $2008 \sim 2012$ & 7 \\
\hline $2013 \sim 2017$ & 6 \\
\hline Age of onset (yr) & $71.23 \pm 10.83 / 69 \quad(57 \sim 91)$ \\
\hline \multicolumn{2}{|l|}{ Sex } \\
\hline Female & $8(61.5)$ \\
\hline Male & $5(38.5)$ \\
\hline Duration of lesion (mo) & $5.38 \pm 3.99 / 3 \quad(1 \sim 12)$ \\
\hline \multicolumn{2}{|l|}{ Localization of the lesion } \\
\hline LE & $8(61.5)$ \\
\hline $\mathrm{HN}$ & $3(23.1)$ \\
\hline UE & $2(15.4)$ \\
\hline Size of tumor $(\mathrm{cm})$ & $3.72 \pm 2.66 / 3 \quad(1 \sim 10)$ \\
\hline \multicolumn{2}{|l|}{ TNM stage } \\
\hline 1 & $1(7.7)$ \\
\hline 2 & $4(30.8)$ \\
\hline 3 & $5(38.5)$ \\
\hline 4 & $3(23.1)$ \\
\hline \multicolumn{2}{|l|}{ Comorbidities } \\
\hline $\mathrm{DM}+\mathrm{HT}+\mathrm{CAD}$ & 7 (53.8) \\
\hline Malignancies & $4(30.8)$ \\
\hline \multicolumn{2}{|l|}{ Treatment } \\
\hline WLE + RT & $8(61.5)$ \\
\hline WLE & $2(15.4)$ \\
\hline $\mathrm{WLE}+\mathrm{CT}$ & $3(23.1)$ \\
\hline Follow-up (mo) & $22.84 \pm 21.52 / 15 \quad(3 \sim 77)$ \\
\hline Survival status & $6(46.2)$ \\
\hline Ex within 1 year & 4 \\
\hline Ex within 3 years & +1 \\
\hline Ex within 5 years & +1 \\
\hline
\end{tabular}

Values are presented as number only, mean \pm standard deviation/ median (range), or number (\%). LE: lower extremity, HN: head and neck, UE: upper extremity, TNM: tumor-node-metastasis, DM: diabetes mellitus, HT: hypertension, CAD: coronary artery disease, WLE: wide local excision, RT: radiotherapy, CT: chemotherapy, Ex: exitus, +1 : additional case.

uated statistically due to small numbers of the patients.

\section{DISCUSSION}

The epidemiologic, demographic, and clinical characteristics of MCC patients shows differences in the literature are mainly consist of single-institution retrospective studies with small numbers in western and eastern populations, and little is known in Turkey aside from a few case reports ${ }^{15-30}$. Increasing incidence of MCC had been reported worldwide; however, incidence was similar in this study in two periods of five years MCC predominantly affects elderly Caucasians, and a male predominance has been reported in large studies ${ }^{7-9}$. Most of our patients were elderly, in their eighth decade of life on average, as re- ported in the literature. Approximately $31 \%$ of our patients were younger than 65 years, and the youngest was 57 years old. A female predominance with a female/male ratio of 1.6 was noticed in this study. Review of literature revealed that the female/male ratio was ranging between 1.12 to 3 in Denmark, Finland, United Kingdom, Germany, Italy, China, and Korea ${ }^{16-23}$. MCC appears to be more common at sun-exposed areas including the head and neck $(46 \% \sim 48 \%)$, in Caucasian populations, nevertheless MCC can arise in UV-protected areas including the extremities $(35 \% \sim 38 \%)$ and trunk $(11 \% \sim 17 \%)^{1,31}$. The lower extremity predilection was reported in African-Americans $^{32}$. In our study, the most common primary site of tumors was the lower extremities followed by the head and neck, although most studies report the reverse sequence $^{7-9}$. Lower extremity was the second most common site in Heath et al.'s report ${ }^{33}$ from Australia. Several reports from New York, the United Kingdom, India, Italy and Greece noticed a predilection for the extremities ${ }^{22-27}$. The last two countries are Mediterranean countries like Turkey, and Hindus are the largest migrant population in the United Kingdom.

MCs are located within the basal epidermis, being concentrated in eccrine glandular ridges of glabrous skin, and within hair follicles which works as slowly adapting mechanoreceptors $^{34}$. The distribution of MCs may help the understanding of their function. There is a site variation in the density of MCs, and probably does not reflect only the effect of chronic sun-exposure because much variation has also been reported in fetal $\operatorname{skin}^{35,36}$. Although the number of the our patients are small the accumulation of primary tumors around the high pressure joint like knee took our attention (Fig. 3). This accumulation may be related with mechanoreseptor function of MCs or a predilection site for our region.

MCPyV has been found in normal skin at all body sites as well as in urine, nasal, and respiratory secretions, and seroprevalence of antibodies increases with age ${ }^{37}$. MCPyV is integrated into genomes of up to $80 \%$ of human MCC. The integration of the virus into the genome precedes the clonal expansion of tumor cells. It has been reported that MCPyV-DNA positivity was more common at sun-exposed area tumors including head, neck, forearm and lower thigh $^{38}$. In the Northern hemisphere, the majority of MCC cases had viral etiology, while in areas with high UV exposure, UV-mediated carcinogenesis is predominant. Although there is no consensus, it has been reported that MCPyV positive MCC shows less metastatic tendency and better prognosis ${ }^{38}$.

Although presentation with other skin cancers is common, only one of our patients had a diagnosis of basosquamous 
Table 3. Demographic and clinical information for each patient

\begin{tabular}{|c|c|c|c|c|c|c|c|c|c|c|c|c|c|c|}
\hline $\begin{array}{c}\text { Patient } \\
\text { no. }\end{array}$ & $\begin{array}{l}\text { Age } \\
(\mathrm{yr})\end{array}$ & Sex & Race & Localization & $\begin{array}{c}\text { Duration } \\
(\mathrm{mo})\end{array}$ & Size $(\mathrm{cm})$ & largin & T & $\mathrm{N}$ & M & Stage & Treatment & $\begin{array}{l}\text { F-up } \\
\text { (mo) }\end{array}$ & $\begin{array}{c}\text { Survival } \\
\text { status }\end{array}$ \\
\hline 1 & 65 & Male & Irkish & . & 1 & $2.5 \times$ & Norativo & II & 0 & 0 & IIA & RT & 3 & Alive \\
\hline 2 & 68 & Male & arkish & eft malar & 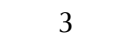 & $2.5 \times 2 \times$ & gative & 11 & 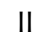 & & IIIB & $\operatorname{LLE}+\mathrm{RT}$ & 12 & live \\
\hline 3 & 61 & Female & Turkish & Right knee & 3 & $5 \times 3.5 \times 3$ & Negative & II & $\mathrm{I}_{\mathrm{b}}$ & 1 & IV & $\mathrm{WLE}+\mathrm{CT}$ & 15 & Alive \\
\hline 4 & 74 & Female & Turkish & Right knee & 6 & $2.8 \times 2.5 \times 1.5$ & Negative & II & 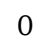 & 0 & IIA & $W L E+R T$ & 25 & Alive \\
\hline 5 & 84 & Female & Turkish & Left arm & 6 & $2.5 \times 1.5 \times 1.4$ & NK & II & $\mathrm{I}_{\mathrm{b}}$ & 0 & IIIB & $W L E+R T$ & 17 & Alive \\
\hline 6 & 69 & Male & Turkish & Left hand & 3 & $1.1 \times 1 \times 1$ & NK & I & 0 & 0 & I & WLE & 77 & Alive \\
\hline 7 & 77 & Male & Turkish & Left knee & 12 & $3 \times 3 \times 3$ & Nega & II & 1 & 0 & IIIB & $W L E+R T$ & 36 & Exitus \\
\hline 8 & 57 & Female & Turkish & Left thigh & 3 & $3.2 \times 2.5 \times 2$ & Negative & II & U & 0 & IIA & $\mathrm{WLE}+\mathrm{RT}$ & 43 & Alive \\
\hline 9 & 82 & Female & Turkish & Right mala & 3 & $7 \times 6 \times 4.5$ & Positive & III & $\mathrm{I}_{\mathrm{b}}$ & 0 & IIIB & WLE & 3 & Exitus \\
\hline 10 & 91 & Female & Turkish & Right toe & 3 & $2.1 \times 2 \times 1$ & Positi & II & S & 0 & IIA & $W L E+R T$ & 5 & Exitus \\
\hline 11 & 59 & Female & Turkish & Right buttock & 12 & $6 \times 6 \times 2.5$ & NK & III & $\mathrm{I}_{\mathrm{b}}$ & 1 & IV & $\mathrm{WLE}+\mathrm{CT}$ & 10 & Exitus \\
\hline 12 & 79 & Female & Turkish & Left malar & 3 & $2.6 \times 1 \times 0.8$ & Posi & II & II & 0 & IIIB & $\mathrm{WLE}+\mathrm{RT}$ & 42 & Exitus \\
\hline 13 & 60 & Female & Turkish & Right cruris & 12 & $10 \times 5.7 \times 4$ & Positive & III & $\mathrm{l}_{\mathrm{b}}$ & $\mathrm{l}_{\mathrm{a}}$ & IV & $W L E+C T$ & 9 & Exitus \\
\hline
\end{tabular}

T: tumor, N: node, M: metastasis, F-up: follow-up, WLE: wide local excision, RT: radiotherapy, CT: chemotherapy, NK: not known.

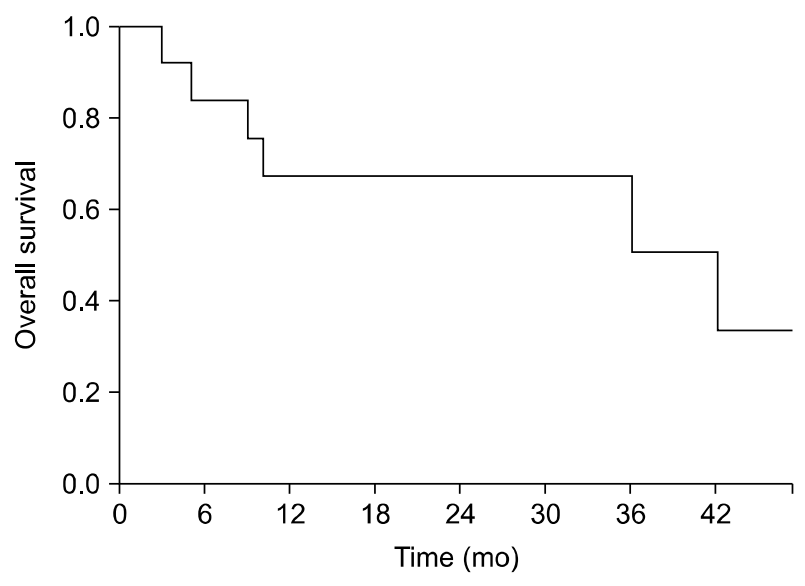

Fig. 4. Kaplan-Meier curves for overall survival of patients: At the time of the study, while the follow-up of four patients (12, $15,17,25$ months) were continuing between 12th to 36th months Plateau shows fell down with a patients' dead at 36th months.

cancer strongly associated with UV exposure; however, this patient had a 15 years history of stage III CLL, which is an another risk factor for the development of non-melanoma skin cancer ${ }^{39}$.

The risk of MCC is significantly increased in patients with other malignancies. A meta-analysis demonstrated that there is an overall increased risk for second malignancies one year after the diagnosis of $\mathrm{MCC}^{40}$. However, four (30.8\%) of our patients had an accompanying malignancy, including breast carcinoma in two patients, CLL and newly diagnosed papillary thyroid carcinoma. This may be a real relationship, but it may also be a simple outcome of a detailed assessment for staging after the diagnosis of MCC in the older population. The higher incidence of MCC in immunosuppressed subjects had been reported. In our study, two $(15.4 \%)$ of the patients had immunosuppression due to immunosuppressive agents.

The acute onset of the tumors in this study occurred at a median of three months; however, some tumors located on the extremities became prominent up to 12 months duration. This may be related to the late detection of lesions which located in an invisible area and neglected by the patients because of the asymptomatic nature of the lesions. The size of the tumor can vary up to $15-\mathrm{cm}$ in diameter, with an average of three $\mathrm{cm}$ at presentation, as we observed. The AEIOU acronym was proposed to define the clinical risk factors of MCC from Australia: Asymptomatic $(88 \%)$, rapidly Expanding $(63 \%)$, Immunosuppression $(8 \%)$, older than 50 years of age $(90 \%)$, and UV exposed area on fair skin $(81 \%)^{33}$. In this study, more than $90 \%$ of the patients were asymptomatic, $69 \%$ of the patients had developed lesions within three months, immunosuppression was noted in $15 \%$ of the patients, all of our patients were older than 50 years, and $76 \%$ of the lesions were located on sun-exposed areas. The clinical and demographic features of our cases overlap with those of the AEIOU acronym with a predilection for the lower extremities.

The eighth (2017) edition of the TNM staging system is recommended by both the AJCC and the Union for International Cancer Control (UICC) is based upon an analysis of 9,387 patients with MCC. At presentation, 65\% of patients had local disease, $26 \%$ of patients had regional lymph node involvement and $8.4 \%$ of patients had distant metastatic disease ${ }^{13}$. In this study, $61 \%$ of the patients had regional and metastatic disease. These reverse results may be explained with increasing knowledge of the MCC and more careful application of staging procedures, improved 
Merkel Cell Carcinoma from Turkey

diagnostic techniques, and the use of different staging methods prior to the AJCC recommendation ${ }^{16,17,20,23,25,26}$. In addition, the high rate of advanced stage may be the natural course of MCC patients seen in our region. There is no standardized management of MCC, and randomized trials are challenging due to relatively small numbers of the reports. Most patients with MCC are treated by WLE followed by adjuvant RT. RT has an important role in patients with MCC to treat occult lymph node disease or minimal residual tumor at the primary site. Systemic CT has demonstrated high response rates in patients with metastatic disease $\mathrm{H}^{41}$. Our experience, compatible with previous literature, RT is the best option for locoregional control, although we were unable to demonstrate this statistically due to the small number of cases. The natural history of MCC is variable. The median OS in this study (42 months) was lower than previous reports, which tends to be approximately 60 to 70 months, although the 5 years OS was within the reported range of $30 \%$ to $60 \%{ }^{11}$. Significant favorable prognostic factors for OS were described as localized disease, female sex, age less than 65 years, and the absence of comorbid conditions ${ }^{13,42}$. Since the number of the patients were small, the effect of factors on survival could not be evaluated statistically. This is a retrospective study with a small number of patients, and we could not investigate the virological features of the cases, which are major limitations of this study.

This is the first largest report from a Turkish population. Female predominance and a lower extremity tendency were remarkable. Clinicians should keep in mind the diagnosis of MCC, especially for asymptomatic fast-growing lesions with older patients. The well-known clinical and demographic characteristics are vital for the differential diagnosis and early management of patients.

\section{ACKNOWLEDGMENT}

We thanks to the Scientific Research Project Unit of Uludag University for language edition support.

\section{CONFLICTS OF INTEREST}

The authors have nothing to disclose.

\section{ORCID}

Serkan Yazici, https://orcid.org/0000-0001-6407-0962 Elif Irmak Yazici, https://orcid.org/0000-0001-7708-8483 Saduman Balaban Adim, https://orcid.org/0000-0002-8243-5440 Emel Bulbul Baskan, https://orcid.org/0000-0002-0144-3263 Kenan Aydoğan, https://orcid.org/0000-0002-0193-1128
Hayriye Saricaoğlu, https://orcid.org/0000-0003-3801-2835

\section{REFERENCES}

1. Coggshall K, Tello TL, North JP, Yu SS. Merkel cell carcinoma: an update and review: pathogenesis, diagnosis, and staging. J Am Acad Dermatol 2018;78:433-442.

2. Toker C. Trabecular carcinoma of the skin. Arch Dermatol 1972;105:107-110.

3. Hodgson NC. Merkel cell carcinoma: changing incidence trends. J Surg Oncol 2005;89:1-4.

4. Lemos BD, Storer BE, Iyer JG, Phillips JL, Bichakjian CK, Fang LC, et al. Pathologic nodal evaluation improves prognostic accuracy in Merkel cell carcinoma: analysis of 5823 cases as the basis of the first consensus staging system. J Am Acad Dermatol 2010;63:751-761.

5. Ratner D, Nelson BR, Brown MD, Johnson TM. Merkel cell carcinoma. J Am Acad Dermatol 1993;29:143-156.

6. Tilling T, Moll I. Which are the cells of origin in merkel cell carcinoma? J Skin Cancer 2012;2012:680410.

7. Albores-Saavedra J, Batich K, Chable-Montero F, Sagy N, Schwartz AM, Henson DE. Merkel cell carcinoma demographics, morphology, and survival based on 3870 cases: a population based study. J Cutan Pathol 2010;37:20-27.

8. Youlden DR, Soyer HP, Youl PH, Fritschi L, Baade PD. Incidence and survival for Merkel cell carcinoma in Queensland, Australia, 1993-2010. JAMA Dermatol 2014;150:864872.

9. Robertson JP, Liang ES, Martin RC. Epidemiology of Merkel cell carcinoma in New Zealand: a population-based study. Br J Dermatol 2015;173:835-837.

10. Moshiri AS, Nghiem P. Milestones in the staging, classification, and biology of Merkel cell carcinoma. J Natl Compr Canc Netw 2014;12:1255-1262.

11. Liang E, Brower JV, Rice SR, Buehler DG, Saha S, Kimple RJ. Merkel cell carcinoma analysis of outcomes: a 30-year experience. PLoS One 2015;10:e0129476.

12. Pilloni L, Manieli C, Senes G, Ribuffo D, Faa G. Merkel cell carcinoma with an unusual immunohistochemical profile. Eur J Histochem 2009;53:e33.

13. Harms KL, Healy MA, Nghiem P, Sober AJ, Johnson TM, Bichakjian $\mathrm{CK}$, et al. Analysis of prognostic factors from 9387 Merkel cell carcinoma cases forms the basis for the new 8th edition AJCC staging system. Ann Surg Oncol 2016; 23:3564-3571.

14. Rødgaard JC, Heje JM, Stolle LB. Merkel cell carcinoma: a single-centre experience. Eur J Plast Surg 2014;37:417-422.

15. Agelli M, Clegg LX. Epidemiology of primary Merkel cell carcinoma in the United States. J Am Acad Dermatol 2003; 49:832-841.

16. Oh SI, Jin US, Chang $\mathrm{H}$, Kwon ST, Minn KW. A retrospective analysis of eight cases of Merkel cell carcinoma. Arch Craniofac Surg 2013;14:41-45.

17. Hohaus K, Köstler E, Schönlebe J, Klemm E, Wollina U. Merkel cell carcinoma--a retrospective analysis of 17 cases. J Eur Acad Dermatol Venereol 2003;17:20-24.

18. Kukko H, Böhling T, Koljonen V, Tukiainen E, Haglund C, 
Pokhrel A, et al. Merkel cell carcinoma-a population-based epidemiological study in Finland with a clinical series of 181 cases. Eur J Cancer 2012;48:737-742.

19. Lyhne D, Lock-Andersen J, Dahlstrøm K, Drzewiecki KT, Balslev E, Muhic A, et al. Rising incidence of Merkel cell carcinoma. J Plast Surg Hand Surg 2011;45:274-280.

20. Koljonen V, Böhling T, Granhroth G, Tukiainen E. Merkel cell carcinoma: a clinicopathological study of 34 patients. Eur J Surg Oncol 2003;29:607-610.

21. Song $\mathrm{PI}$, Liang $\mathrm{H}$, Wei WQ, Jiang $\mathrm{YQ}$, Smith JS, Qiao $\mathrm{YL}$. The clinical profile of Merkel cell carcinoma in mainland China. Int J Dermatol 2012;51:1054-1059.

22. Bajetta E, Celio L, Platania M, Lo Vullo S, Patuzzo R, Maurichi $A$, et al. Single-institution series of early-stage Merkel cell carcinoma: long-term outcomes in 95 patients managed with surgery alone. Ann Surg Oncol 2009;16:2985-2993.

23. Dancey AL, Rayatt SS, Soon C, Ilchshyn A, Brown I, Srivastava S. Merkel cell carcinoma: a report of 34 cases and literature review. J Plast Reconstr Aesthet Surg 2006;59:1294-1299.

24. Cirillo F, Vismarra M, Cafaro I, Martinotti M. Merkel cell carcinoma: a retrospective study on 48 cases and review of literature. J Oncol 2012;2012:749030.

25. Rekhi B, Kane SV, Jambhekar NA. Clinicopathological spectrum of a series of Merkel cell carcinomas diagnosed at a tertiary cancer referral center in India, with current concepts. Ann Diagn Pathol 2015;19:341-346.

26. Pectasides D, Papaxoinis G, Pectasides E, Galani H, Razi E, Katodrytis $\mathrm{N}$, et al. Merkel cell carcinoma of the skin: a retrospective study of 24 cases by the Hellenic Cooperative Oncology Group. Oncology 2007;72:211-218.

27. Allen PJ, Bowne WB, Jaques DP, Brennan MF, Busam K, Coit DG. Merkel cell carcinoma: prognosis and treatment of patients from a single institution. J Clin Oncol 2005;23: 2300-2309.

28. Açıkalın A, Paydaş S, Güleç ÜK, Uğuz A, Gümürdülü D. A unique case of merkel cell carcinoma with ovarian metastasis. Balkan Med J 2014;31:356-359.

29. Dogu MH, Sari I, Hacioglu S, Degirmencioglu S, Şen N, Keskin A. Two rare diagnoses during chronic lymphocytic leukaemia follow-up: Kaposi's sarcoma and Merkel cell carcinoma. Scott Med J 2016;61:60-63.

30. Esen BA, Pinarbasi B, Buyukbabani N, Baykal C, Cizmeci $\mathrm{O}$, Demir $\mathrm{K}$, et al. Merkel-cell carcinoma arising after liver transplantation: a case report. Transplant Proc 2005;37:44134415.
31. Asgari MM, Sokil MM, Warton EM, lyer J, Paulson KG, Nghiem P. Effect of host, tumor, diagnostic, and treatment variables on outcomes in a large cohort with Merkel cell carcinoma. JAMA Dermatol 2014;150:716-723.

32. Fitzgerald TL, Dennis S, Kachare SD, Vohra NA, Wong JH, Zervos EE. Dramatic increase in the incidence and mortality from Merkel cell carcinoma in the United States. Am Surg 2015;81:802-806.

33. Heath $M$, Jaimes $N$, Lemos $B$, Mostaghimi $A$, Wang LC, Peñas PF, et al. Clinical characteristics of Merkel cell carcinoma at diagnosis in 195 patients: the AEIOU features. J Am Acad Dermatol 2008;58:375-381.

34. Moll I, Roessler M, Brandner JM, Eispert AC, Houdek P, Moll R. Human Merkel cells--aspects of cell biology, distribution and functions. Eur J Cell Biol 2005;84:259-271.

35. Lacour JP, Dubois D, Pisani A, Ortonne JP. Anatomical mapping of Merkel cells in normal human adult epidermis. Br J Dermatol 1991;125:535-542.

36. Moll R, Moll I, Franke WW. Identification of Merkel cells in human skin by specific cytokeratin antibodies: changes of cell density and distribution in fetal and adult plantar epidermis. Differentiation 1984;28:136-154.

37. Viscidi RP, Rollison DE, Sondak VK, Silver B, Messina JL, Giuliano AR, et al. Age-specific seroprevalence of Merkel cell polyomavirus, BK virus, and JC virus. Clin Vaccine Immunol 2011;18:1737-1743.

38. Higaki-Mori $\mathrm{H}$, Kuwamoto $\mathrm{S}$, Iwasaki T, Kato M, Murakami I, Nagata K, et al. Association of Merkel cell polyomavirus infection with clinicopathological differences in Merkel cell carcinoma. Hum Pathol 2012;43:2282-2291.

39. Tessari G, Girolomoni G. Nonmelanoma skin cancer in solid organ transplant recipients: update on epidemiology, risk factors, and management. Dermatol Surg 2012;38:16221630.

40. Saxena A, Rubens M, Ramamoorthy V, Khan H. Risk of second cancers in merkel cell carcinoma: a meta-analysis of population based cohort studies. J Skin Cancer 2014;2014: 184245.

41. Tello TL, Coggshall K, Yom SS, Yu SS. Merkel cell carcinoma: an update and review: current and future therapy. J Am Acad Dermatol 2018;78:445-454.

42. Eng TY, Boersma MG, Fuller CD, Cavanaugh SX, Valenzuela F, Herman TS. Treatment of merkel cell carcinoma. Am J Clin Oncol 2004;27:510-515. 